\title{
INDEPENDENT FACTORS FOR POOR PROGNOSIS IN YOUNG PATIENTS WITH STAGE I-III BREAST CANCER
}

\author{
Ivan Erić ${ }^{1,2}$, Anamarija Petek Erić1,2, Ivan Koprivčićc, ${ }^{1,2}$, Marko Babić, ${ }^{1,2}$, \\ Stana Pačarić ${ }^{2}$ and Bojan Trogrlić, ${ }^{1,2}$ \\ ${ }^{1}$ Josip Juraj Strossmayer University in Osijek, Faculty of Medicine, Osijek, Croatia; \\ ${ }^{2}$ Osijek University Hospital Centre, Osijek, Croatia
}

\begin{abstract}
SUMMARY - Breast cancer is the most common malignancy in the population of women under 40 years of age. Young age is an independent factor for poor prognosis. In this research, we tried to establish other factors for poor prognosis in stage I-III breast cancer. The following parameters were observed: tumor size, lymph node status, histologic grade, hormonal receptor status, Ki-67 prognostic index, Her2 neu status, histologic type of the tumor, local recurrence and metastases. Logistic regression was used to evaluate the effect of specific factors on the probability of lethal outcome and development of distant metastases. Our patients showed a predominance of T1 tumor (49.4\%), had positive lymph nodes (62\%) and most of them were pN1 (61.2\%). Up to one-third of patients had triple negative status. Ki-67 proliferation index was high (25\%). Multicentric tumor was detected in $23 \%$ of patients. There was no difference in overall survival between the two types of surgical procedures. $\mathrm{Pa}$ tients with $\mathrm{pN} 0$ status had better overall survival. Breast cancer in the population of young women has a more aggressive nature. Study results indicated positive lymph node status as an independent factor for poor prognosis of stage I-III breast cancer.
\end{abstract}

Key words: Breast cancer; Young women; Multivariate analysis; Independent risk factor

\section{Introduction}

Breast cancer represents a global public health issue. It is the most common malignancy and mortality factor in the population of women. Due to the expansion of novel therapeutic options, from surgical and oncologic perspective, and with greater potential for recovery, breast cancer is one of the most researched malignancies in the past twenty years. Young women with breast cancer are considered to be those under 40 years of age $\mathrm{e}^{1,2}$. In this population, breast carcinoma represents the most common malignant disease with highest mortality, although breast cancer accounts for $6 \%$ of the total number of cancer cases ${ }^{3}$. Numerous clinical studies have

Correspondence to: Ivan Erić, MD, Osijek University Hospital Centre, Josipa Huttlera 4, HR-31000 Osijek, Croatia

E-mail: ivaneric1@gmail.com

Received January 31, 2019, accepted April 16, 2019 confirmed that breast cancer in young women has a higher histologic grade, unfavorable hormonal status, and overall higher death rate compared to the older population of women ${ }^{4-6}$. Young age is an adverse prognostic factor in primary breast cancer. Various studies found young women to have worse outcomes than older patients ${ }^{7,8}$. Young age is also an independent risk factor for disease-free survival (DFS) and overall survival (OS) in women with operable breast cancer ${ }^{9,10}$. In the group of young women, there are limited data on prognostic factors. Only a few studies recognize nodal status, estrogen receptor status and molecular subtype as independent factors for poor survival ${ }^{11,12}$.

We recognized young age as an independent factor for poor prognosis but also wanted to establish other possible independent factors for DFS and OS in the group of young women with breast cancer from our population. 


\section{Patients and Methods}

This was a retrospective study. Data were collected from medical charts of young female patients having undergone surgical treatment at the Department of Surgery, Osijek University Hospital Centre, Osijek, Croatia, during the 2002-2010 period. Study patients were under 40 years of age at the time of surgery. Data on the following parameters were collected: tumor size, lymph node status, histologic grade, hormonal receptor status, Ki-67 prognostic index, Her2 neu status, histologic type of tumor, local recurrence, metastases, and outcome (alive or death). All patients included in the study had complete medical documentation. Those with incomplete documentation and data were excluded from the study. All study patients had stage I-III tumor. Patients who had positive distant metastasis (M) at the time of diagnosis were not included in the study. All patients were monitored during routine and urgent checkups. All patients included in this study were monitored for 5-13 (median 8.7) years. We collected data on 79 young female patients, median age 37 (range 33-39) years.

Breast tissue was fixed, embedded in paraffin and cut into 5- $\mu \mathrm{m}$ sections. After that, it was stained and observed under a microscope. Hormonal status, Her2 neu status and Ki 67 were determined by immunochemical staining. Among patients with Her2 neu 2+, the FISH method was performed to determine whether the patient was Her2 neu positive or negative. Histologic grading of breast carcinoma was performed by Elston and Ellis method. We used the TNM (tumornodes-metastases) classification of the American Joint Committee on Cancer Staging System for Breast Cancer, 2010 ${ }^{13,14}$.

Local recurrence is defined as recurrence in the field of mastectomy or in the original tumor location for breast conserving resection. Local recurrence was diagnosed pathologically after surgical biopsy. Metastases are defined as recurrence of the tumor in distant organ during regular or urgent follow up examinations using abdominal ultrasound, lung radiography, bone scintigraphy, surgical biopsy, computed tomography (CT), magnetic resonance imaging (MRI) and positron emission/computed tomography (PET/CT) scans. Outcome was defined as the patient being dead or alive at the end of the follow up period.
Table 1. Study parameters in young women with breast cancer

\begin{tabular}{|c|c|}
\hline $\begin{array}{l}\text { Affected side, n (\%) } \\
\text { right } \\
\text { left }\end{array}$ & $\begin{array}{l}40(50.6) \\
39(49.4)\end{array}$ \\
\hline $\begin{array}{l}\text { Histologic type, } \mathbf{n}(\%) \\
\text { ductal invasive } \\
\text { lobular invasive } \\
\text { other }\end{array}$ & $\begin{array}{l}56(70.9) \\
11(13.9) \\
12(15.2)\end{array}$ \\
\hline $\begin{array}{l}\text { Tumor size (T), } \mathbf{n}(\%) \\
\text { T1 } \leq 2 \mathrm{~cm} \\
\text { T2 }>2 \mathrm{~cm}, \leq 5 \mathrm{~cm} \\
\text { T3 }>5 \mathrm{~cm} \\
\text { T4 any size with skin or chest wall } \\
\text { spread }\end{array}$ & $\begin{array}{l}39(49.4) \\
30(38) \\
7(8.9) \\
3(3.8)\end{array}$ \\
\hline Positive lymph nodes, $\mathrm{n}(\%)$ & $49(62)$ \\
\hline $\begin{array}{l}\text { Lymph nodes status, } \mathrm{n}(\%) \\
\text { 1-3 lymph nodes } \\
\text { 4-9 lymph nodes } \\
\geq 10 \text { lymph nodes }\end{array}$ & $\begin{array}{l}30(61.2) \\
13(26.5) \\
6(12.2)\end{array}$ \\
\hline $\begin{array}{l}\text { Estrogen status, } \mathbf{n}(\%) \\
\text { negative } \\
\text { positive }\end{array}$ & $\begin{array}{l}36(45.6) \\
43(54.4)\end{array}$ \\
\hline $\begin{array}{l}\text { Progesterone status, } \mathbf{n}(\%) \\
\text { negative } \\
\text { positive }\end{array}$ & $\begin{array}{l}35(44.3) \\
44(55.7)\end{array}$ \\
\hline $\begin{array}{l}\text { HER2 neu status, } \mathbf{n}(\%) \\
\text { negative } \\
\text { positive }\end{array}$ & $\begin{array}{l}60(75.9) \\
19(24.1)\end{array}$ \\
\hline Triple negative, $\mathrm{n}(\%)$ & $25(32.1)$ \\
\hline Ki67, median (25\%-75\%) & $25(11-48)$ \\
\hline $\begin{array}{l}\text { Type of surgical procedure, } \mathbf{n}(\%) \\
\text { modified radical mastectomy } \\
\text { breast conserving resection }\end{array}$ & $\begin{array}{ll}52 & (65.8) \\
27 & (34.2)\end{array}$ \\
\hline Multicentric tumor position, $\mathrm{n}(\%)$ & $18(23.1)$ \\
\hline $\begin{array}{l}\text { Histologic grade, } \mathbf{n}(\%) \\
\text { I } \\
\text { II } \\
\text { III }\end{array}$ & $\begin{array}{l}13(16.5) \\
43(54.4) \\
23(29.1)\end{array}$ \\
\hline Local recurrence, n (\%) & $\begin{array}{l}\text { MRM } 0(0) \\
\text { BCR } 3(3.8)\end{array}$ \\
\hline Metastases, n (\%) & $21(26.6)$ \\
\hline $\begin{array}{l}\text { Outcome, } \mathbf{n}(\%) \\
\text { alive } \\
\text { dead }\end{array}$ & $\begin{array}{l}64(81) \\
15(19)\end{array}$ \\
\hline
\end{tabular}


Table 2. Impact of parameters on prediction of lethal outcome (univariate regression analysis)

\begin{tabular}{|c|c|c|c|c|}
\hline Variable & $\beta$ & $\mathrm{p}$ & $\begin{array}{l}\text { Odds ratio } \\
(\mathrm{OR})\end{array}$ & $\begin{array}{l}95 \% \text { confidence } \\
\text { interval }\end{array}$ \\
\hline Age & -0.025 & 0.75 & 0.975 & $0.84-0.94$ \\
\hline $\begin{array}{l}\text { Histology type } \\
\text { ductal invasive } \\
\text { lobular invasive } \\
\text { other }\end{array}$ & $\begin{array}{l}-1.003 \\
-0.087\end{array}$ & $\begin{array}{l}0.84 \\
0.36 \\
0.91\end{array}$ & $\begin{array}{l}0.367 \\
0.917\end{array}$ & $\begin{array}{l}0.04-3.15 \\
0.17-4.89\end{array}$ \\
\hline Tumor size $\mathrm{T}(\mathrm{cm})$ & 0.079 & 0.54 & 1.083 & $0.837-1.40$ \\
\hline $\begin{array}{l}\text { Lymph nodes status } \\
\text { pN0 } \\
\text { pN1 } \\
\text { pN2 } \\
\text { pN3 }\end{array}$ & $\begin{array}{l}2.178 \\
2.556 \\
3.367\end{array}$ & $\begin{array}{l}0.04 \\
0.03 \\
0.03 \\
0.01\end{array}$ & $\begin{array}{l}8.8 \\
12.89 \\
29 \\
\end{array}$ & $\begin{array}{l}1.012-76.9 \\
1.27-130.5 \\
2.3-373.7\end{array}$ \\
\hline $\begin{array}{l}\text { Estrogen } \\
\text { negative } \\
\text { positive }\end{array}$ & -1.073 & 0.04 & 0.342 & $0.105-0.812$ \\
\hline $\begin{array}{l}\text { Progesterone } \\
\text { negative } \\
\text { positive } \\
\end{array}$ & -0.785 & 0.18 & 0.456 & $0.145-1.44$ \\
\hline $\begin{array}{l}\text { HER2 neu } \\
\text { negative } \\
\text { positive }\end{array}$ & -0.288 & 0.68 & 0.750 & $0.188-2.9$ \\
\hline $\mathrm{Ki}-67(\%)$ & 0.019 & 0.03 & 1.019 & $0.797-0.97$ \\
\hline $\begin{array}{l}\text { Type of surgery } \\
\text { BCR } \\
\text { MRM }\end{array}$ & 0.875 & 0.21 & 2.4 & $0.614-9.4$ \\
\hline $\begin{array}{l}\text { Multicentric positior } \\
\text { no } \\
\text { yes }\end{array}$ & 1.041 & 0.09 & 2.833 & $0.845-9.49$ \\
\hline $\begin{array}{l}\text { Triple negative } \\
\text { no } \\
\text { yes }\end{array}$ & 0.783 & 0.18 & 2.187 & $0.691-6.92$ \\
\hline $\begin{array}{l}\text { Histology grade } \\
\text { I } \\
\text { II } \\
\text { III }\end{array}$ & $\begin{array}{l}0.229 \\
0.424 \\
\end{array}$ & $\begin{array}{l}0.89 \\
0.79 \\
0.64 \\
\end{array}$ & $\begin{array}{l}1.257 \\
1.528 \\
\end{array}$ & \begin{tabular}{|l|}
$0.232-6.8$ \\
$0.252-9.3$ \\
\end{tabular} \\
\hline $\begin{array}{l}\text { Local recurrence } \\
\text { no } \\
\text { yes }\end{array}$ & 2.271 & 0.07 & 9.692 & $0.82-114.9$ \\
\hline $\begin{array}{l}\text { Metastases } \\
\text { no } \\
\text { yes } \\
\end{array}$ & 22.119 & 0.997 & $4.0 \times 109$ & 0 \\
\hline
\end{tabular}

$\mathrm{BCR}=$ breast conserving resection; $\mathrm{MRM}=$ modified radical mastectomy

Statistical analysis was performed with SPSS 13.0 (Chicago, IL, USA) software. Logistic regression (univariate and multivariate) was used to evaluate the im- pact of several factors on the probability of negative outcome in study subjects. 
Table 3. Impact of parameters on prediction of lethal outcome (multivariate regression analysis)

\begin{tabular}{|l|l|l|l|l|}
\hline Variable & $\beta$ & $\mathrm{p}$ & $\begin{array}{l}\text { Odds ratio } \\
(\text { OR })\end{array}$ & 95\% confidence interval \\
\hline $\begin{array}{l}\text { Lymph nodes status } \\
\text { pN0 }\end{array}$ & & 0.04 & & \\
pN1 & 2.016 & 0.09 & 7.509 & $0.707-79.770$ \\
pN2 & 3.433 & 0.01 & 30.97 & $2.044-468.9$ \\
pN3 & 3.579 & 0.01 & 35.83 & $2.339-548.8$ \\
\hline Estrogen positive & -1.856 & 0.14 & 0.156 & $0.013-1.871$ \\
\hline Progesterone positive & 0.677 & 0.57 & 1.968 & $0.191-20.296$ \\
\hline Ki-67 (\%) & 0.019 & 0.17 & 1.019 & $0.992-1.048$ \\
\hline Local recurrence & & & & \\
$\quad$ yes & 2.240 & 0.12 & 9.398 & $0.553-159.78$ \\
\hline Constant & -3.843 & 0.005 & 0.021 & \\
\hline
\end{tabular}

\section{Results}

Data were collected on 79 patients, median age 37 (range 33-39) years (Table 1). There were no significant differences according to the side operated on. Invasive ductal carcinoma was the most common histologic type of tumor (70.9\%). Invasive lobular carcinoma was the second most common type (13.9\%).

Regarding the size of the tumor, most patients had $\mathrm{T} 1$ and $\mathrm{T} 2(87.4 \%)$ tumor size, with a predominance of tumor size $\leq 2 \mathrm{~cm}$ (49.4\%). The majority of patients had positive lymph nodes $(62 \%)$, most of them with pN1 status (1-3 positive nodes; $61.2 \%$ ). There were no significant differences in estrogen or progesterone status. The majority of patients were her 2 neu negative (75.9\%) and up to one-third of patients had triple negative immunohistochemical status. Ki-67 proliferation index was rather high (25\%; interquartile range $11 \%$ to up to $46 \%)$. We found a high incidence of multicentric tumors $(n=18,23.15 \%)$ in our group of young women. More than one-half of patients were histology grade II (54.4\%) (Table 1).

Modified radical mastectomy was the preferred type of surgical procedure, performed in $65.8 \%$ of patients. Only three patients developed local recurrence. They all were primarily treated with breast conserving resection.

At the end of follow up, metastases were detected in $26.6 \%$ of patients and 15 (19\%) of them died (Table 1).

\section{Effect of parameters on predicting lethal outcome}

Logistic regression was used to estimate the potential impact of specific factors on the possible lethal out- come in the study group of patients. The model contains fourteen parameters: age, histologic type, tumor size, lymph node status, estrogen status, progesterone status, Her2 neu, Ki-67, type of surgical procedure, multicentric position, triple negative status, histology grade, local recurrence, and metastases (Table 2).

From the predictor variables that showed statistical significance, and exclusion of variables that did not change the probability $(\mathrm{P})$ model by $20 \%$, the following five variables were selected for the model on which to apply multivariate logistic regression: estrogen and progesterone positive status, lymph node status, Ki-67, and local recurrence. The model was statistically significant, $\chi^{2}=20.4(\mathrm{df}=7, \mathrm{p}=0.005)$, and explained between 22.7\% (after Cox \& Snell) and 36.6\% (after Negelkerke) of variance for death outcome, and accurately classified $86.1 \%$ of cases. The strongest independent factor for death outcome was lymph node status (Table 3).

\section{Effect of parameters on predicting development of metastases}

The probability of developing distant metastases in the study sample was evaluated by screening for the specific factors applying the logistic regression methods. The model contains thirteen parameters: age, histologic type, tumor size, lymph node status, estrogen status, progesterone status, Her2 neu, Ki-67, type of surgical procedure, multicentric position, triple negative status, histology grade, and local recurrence (Table 4).

Four predictor variables that showed statistical significance were chosen for the model on which multi- 
Table 4. Impact of parameters on prediction of metastasis development (univariate regression analysis)

\begin{tabular}{|c|c|c|c|c|}
\hline Variable & $\beta$ & $\mathrm{p}$ & $\begin{array}{l}\text { Odds ratio } \\
(\mathrm{OR})\end{array}$ & $\begin{array}{l}\text { 95\% confidence } \\
\text { interval }\end{array}$ \\
\hline Age & -0.157 & 0.03 & 0.855 & $0.745-0.981$ \\
\hline $\begin{array}{l}\text { Histology type } \\
\text { ductal invasive } \\
\text { lobular invasive } \\
\text { other }\end{array}$ & $\begin{array}{l}-0.674 \\
-0.556\end{array}$ & $\begin{array}{l}0.81 \\
0.42 \\
0.51\end{array}$ & $\begin{array}{l}0.510 \\
0.574\end{array}$ & $\begin{array}{l}0.099-2.614 \\
0.110-2.989\end{array}$ \\
\hline Tumor size $\mathrm{T}(\mathrm{cm})$ & 0.048 & 0.70 & 1.049 & $0.823-1.337$ \\
\hline $\begin{array}{l}\text { Lymph nodes status } \\
\text { pN0 } \\
\text { pN1 } \\
\text { pN2 } \\
\text { pN3 }\end{array}$ & $\begin{array}{l}1.350 \\
1.727 \\
2.890\end{array}$ & $\begin{array}{l}0.04 \\
0.06 \\
0.04 \\
0.006\end{array}$ & $\begin{array}{l}3.857 \\
5.625 \\
18\end{array}$ & $\begin{array}{l}0.927-16.048 \\
1.097-28.83 \\
2.26-143.3\end{array}$ \\
\hline $\begin{array}{l}\text { Estrogen } \\
\text { negative } \\
\text { positive }\end{array}$ & -0.905 & 0.08 & 0.404 & $0.145-1.128$ \\
\hline $\begin{array}{l}\text { Progesterone } \\
\text { negative } \\
\text { positive }\end{array}$ & -0.708 & 0.17 & 0.493 & $0.179-1.356$ \\
\hline $\begin{array}{l}\text { HER2 neu } \\
\text { negative } \\
\text { positive }\end{array}$ & 0.651 & 0.25 & 1.917 & $0.633-5.802$ \\
\hline $\mathrm{Ki}-67(\%)$ & 0.007 & 0.52 & 1.007 & $0.987-1.027$ \\
\hline $\begin{array}{l}\text { Type of surgery } \\
\text { BCR } \\
\text { MRM }\end{array}$ & -0.671 & 0.25 & 0.511 & $0.164-1.592$ \\
\hline $\begin{array}{l}\text { Multicentric position } \\
\text { no } \\
\text { yes }\end{array}$ & 1.386 & 0.015 & 4 & $1.305-12.256$ \\
\hline $\begin{array}{l}\text { Triple negative } \\
\text { no } \\
\text { yes }\end{array}$ & 0.370 & 0.49 & 1.448 & $0.508-4.128$ \\
\hline $\begin{array}{l}\text { Histology grade } \\
\text { I } \\
\text { II } \\
\text { III }\end{array}$ & $\begin{array}{l}0.756 \\
0.878\end{array}$ & $\begin{array}{l}0.60 \\
0.37 \\
0.33 \\
\end{array}$ & $\begin{array}{l}2.129 \\
2.406\end{array}$ & $\begin{array}{l}0.410-11.057 \\
0.419-13.832 \\
\end{array}$ \\
\hline $\begin{array}{l}\text { Local recurrence } \\
\text { no } \\
\text { yes }\end{array}$ & 22.37 & 0.99 & $5.2 \times 109$ & 0 \\
\hline
\end{tabular}

$\mathrm{BCR}=$ breast conserving resection; $\mathrm{MRM}=$ modified radical mastectomy

variate logistic regression was applied. These variables were found to be predictors for metastasis development: age, lymph node status, estrogen status and multicentric position. The model was statistically significant, $\chi^{2}=20.1(\mathrm{df}=5, \mathrm{p}=0.001)$, and explained between
22.5\% (after Cox \& Snell) and 32.7\% (after Negelkerke) of variance for metastasis development, and accurately classified $78.5 \%$ of cases. The strongest independent factor for metastases was lymph node status (Table 5). 
Table 5. Impact of parameters on prediction of metastasis development (multivariate regression analysis)

\begin{tabular}{|l|l|l|l|l|}
\hline Variable & $\beta$ & $p$ & $\begin{array}{l}\text { Odds ratio } \\
(\text { OR })\end{array}$ & $\begin{array}{l}\text { 95\% confidence } \\
\text { interval }\end{array}$ \\
\hline $\begin{array}{l}\text { Lymph nodes status } \\
\text { pN0 }\end{array}$ & & & & \\
pN1 & 1.626 & 0.07 & & \\
pN2 & 1.995 & 0.04 & 5.086 & 7.354 \\
pN3 & 3.523 & 0.02 & 33.874 & $1.020-25.349$ \\
\hline Estrogen positive & -1.52 & 0.03 & 0.219 & $1.718-667.8$ \\
\hline Age & -0.160 & 0.05 & 0.852 & $0.054-0.885$ \\
\hline Multicentric position, yes & 0.719 & 0.39 & 2.052 & $0.723-1.003$ \\
\hline Constant & 3.854 & 0.18 & 47.1 & $0.054-0.885$ \\
\hline
\end{tabular}

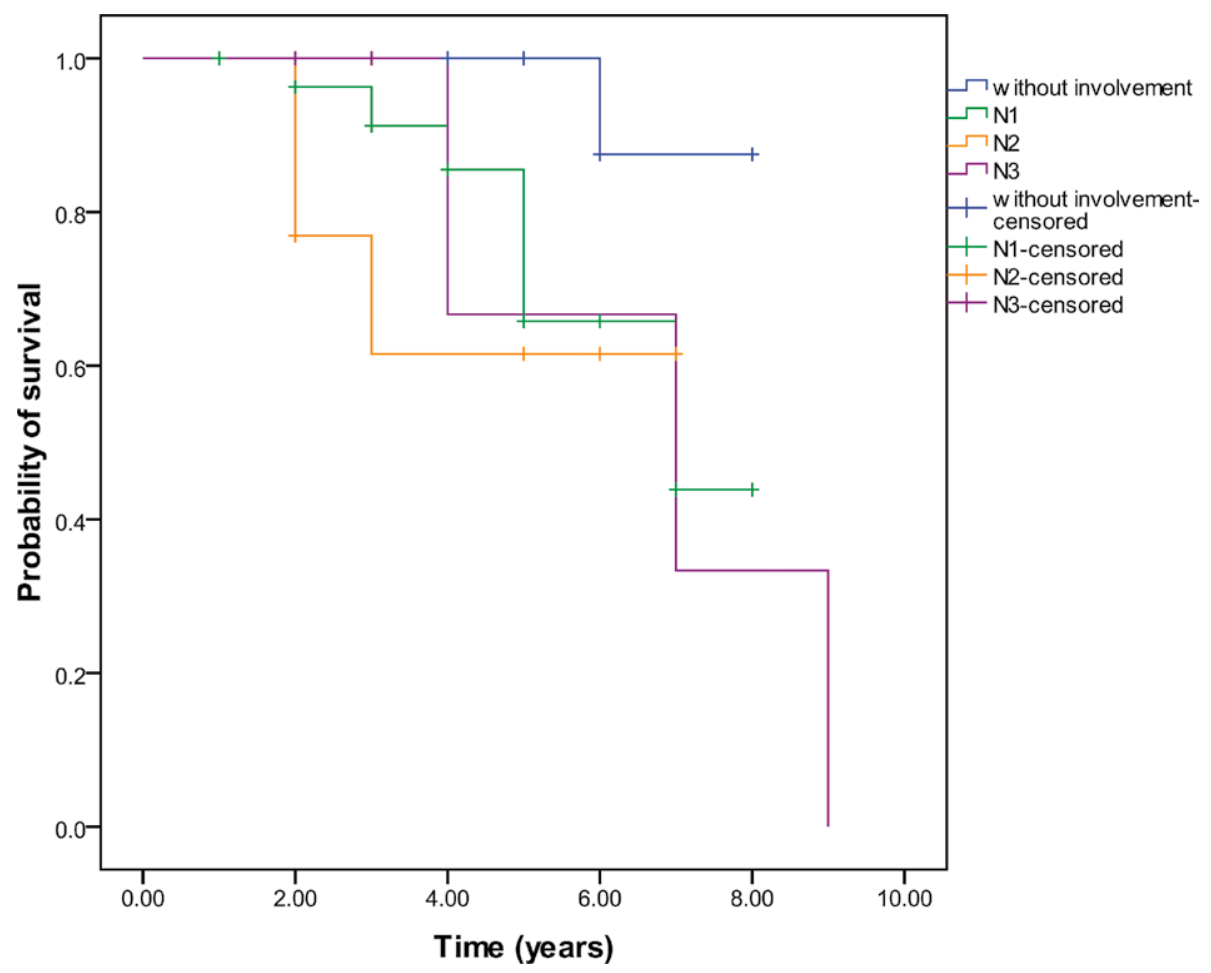

Fig. 1. Kaplan-Meier's analysis of survival with lymph node involvement.

\section{Kaplan-Meier's analysis of survival}

Kaplan-Meier's analysis of survival was applied in patients with distant metastases. Patients without positive lymph node $(\mathrm{n}=8)$ had OS at 7.8 years $(95 \% \mathrm{CI}$ 7.3-8,2). Patients with N1 ( $\mathrm{n}=27)$ had OS at 6.5 years $(95 \%$ CI 5,6-7,4). Lowest OS was recorded in patients with $\mathrm{N} 2(\mathrm{n}=13)$, at 5.2 years (95\% CI 3.8-6.7). $\mathrm{Pa}-$ tients with $\mathrm{N} 3(\mathrm{n}=3)$ had OS at 6.7 years $(95 \% \mathrm{CI}$ 3.8-9.5). Patients with positive $\mathrm{N}$ had poor $\mathrm{OS}$, but without differences according to the number of positive nodes (Mantel-Cox test, p=0.08) (Fig. 1).

The mean survival period in our group of young $\mathrm{pa}^{-}$ tients was 7.3 years (95\% CI 6.6 to 8.1 ). Survival time of patients operated on with modified radical mastectomy with axillary dissection was 6.8 years $(95 \%$ CI 5.7 to 7.8), and of patients operated on with breast conserving resection 7.3 years (95\% CI 6.6-8), with no significant difference (Mantel-Cox test, $\mathrm{p}=0.13$ ) (Fig. 2). 


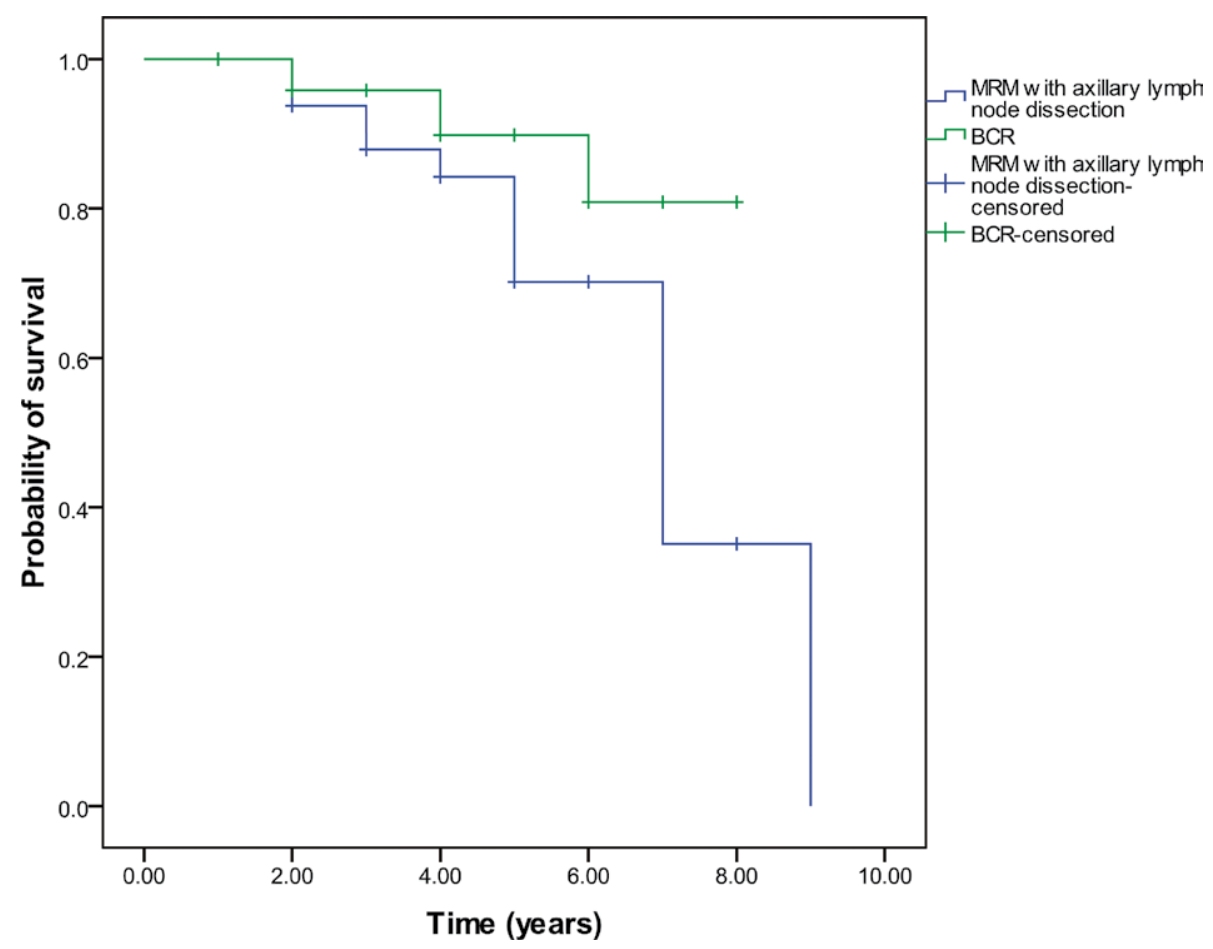

Fig. 2. Kaplan-Meier's analysis of survival with type of surgical procedure.

$\mathrm{BCR}=$ breast conserving resection; $\mathrm{MRM}=$ modified radical mastectomy

\section{Discussion}

Breast cancer in the population of young women accounted for only 5\%-7\% of all breast cancer patients $^{3}$. In Far East countries, the incidence of breast cancer in young patients was found to be twofold that in developed countries ${ }^{10}$. Breast cancer among young women is considered to have a more aggressive nature and higher tumor grade with more vascular invasion than breast cancer in older women ${ }^{4}$. When compared to older women, breast cancer in younger women tends to have a worse prognosis in terms of OS and DFS ${ }^{9,10}$. Young age has been identified as an independent factor for poor prognosis ${ }^{9,15}$.

In our sample, we found invasive ductal carcinoma as the most frequent histologic type of tumor. The second most common type was invasive lobular carcinoma. Among other different studies, Rosenberg et al. in their case-control study confirmed invasive ductal carcinoma as the most frequent one, and invasive lobular carcinoma as the second most common ${ }^{16,17}$. We found a predominance of tumors smaller than $5 \mathrm{~cm}$, especially $\mathrm{T} 1$, which is consistent with the findings report- ed by Colleoni et al. ${ }^{18}$. Prognostic value of tumor size is independent of the state of lymph nodes. Patients with small tumors have better prognosis ${ }^{19,20}$. The prognosis of multicentric tumor is worse than for solid tumors of similar size (often axillary metastases) ${ }^{21}$. Multicentric cancer has worse biologic behavior with frequently present multiple foci and therefore should be considered in planning adjuvant treatments ${ }^{22}$. We found a rather high proportion of multicentric breast cancer.

Positive axillary lymph nodes have been considered as the most important prognostic factor for poor prognosis of breast cancer patients ${ }^{19}$. We found the majority of our patients to have positive lymph nodes. Our positive lymph node patients had worse OS and DFS (positive distant metastases) than lymph node negative patients, however, without difference between $\mathrm{pN} 1-$ pN3 lymph node status. This is somewhat different from the findings reported from one study, which established difference in OS between $\mathrm{pN} 1$ and a greater number of lymph nodes involved ${ }^{23}$. Tai et al. also report on difference in prognosis within $\mathrm{pN} 1$ group between 1-2 and 3 lymph nodes involved ${ }^{24}$. Our findings might be somewhat imprecise due to the small sample size. 
Triple-negative breast cancer is more aggressive, more likely to metastasize, and has more frequent recurrences after treatment. This is visible in the first 5 years after treatment. Generally, triple negative breast cancer has poor prognosis and higher mortality rate compared to other molecular subtypes ${ }^{25}$. In our study sample, up to one-third of patients were triple negative. Studies emphasize that the Ki-67 index $\geq 20$ is a poor prognostic sign. Breast cancer patients with high $\mathrm{Ki}-67$ had a significantly worse prognosis due to local recurrence, distant metastasis and poor $\mathrm{OS}^{26,27}$. In our study, $\mathrm{Ki}-67$ was found to be $25 \%$, which is a high value pointing to poor prognosis of the disease in our group of young women.

When compared with modified radical mastectomy, breast conserving surgery is similar in OS and the chance for distant metastasis development. Of course, breast conserving resection must be combined with radiotherapy. Breast conserving resection has more local recurrences; all local recurrences in our sample were in the breast conserving resection group. We proved that there was no difference between these two surgical procedures in OS, which is consistent with recent literature $^{28,29}$.

On statistical analysis, we identified local recurrence, hormone receptor status, lymph node status and $\mathrm{Ki}-67$ index as predictors of poor OS. Lymph node status, hormone receptor status and multicentric position were predictive of developing distant metastases. However, lymph node status was an independent factor for both OS and DFS. Other authors recognize hormone receptor status and lymph node status as predictors of poor prognosis ${ }^{11,12}$.

\section{Conclusion}

Breast cancer in the population of young women has a more aggressive nature, positive lymph nodes, often triple negative molecular subtype, high $\mathrm{Ki}-67$ index, multicentric tumor position and distant metastases. These are predictors of poor prognosis, but positive lymph node status is an independent prognostic factor for OS and DFS.

\section{References}

1. Collins LC, Marotti JD, Gelber S, Cole K, Ruddy K, Kereakoglow S, Brachtel EF, Schapira L, Come SE, Winer EP, Par- tridge AH. Pathologic features and molecular phenotype by patient age in a large cohort of young women with breast cancer. Breast Cancer Res Treat. 2012 Feb;131(3):1061-6. doi: 10.1007/s10549-011-1872-9. Epub 2011 Nov 13.

2. Zhou P, Recht A. Young age and outcome for women with early-stage invasive breast carcinoma. Cancer. 2004;101: 1264-74.

3. Brinton LA, Sherman ME, Carreon JD, Anderson WF. Recent trends in breast cancer among younger women in the United States. J Natl Cancer Inst. 2008 Nov 19;100(22):1643-8. doi: 10.1093/jnci/djn344. Epub 2008 Nov 11.

4. Walker RA, Lees E, Webb MB, Dearing SJ. Breast carcinomas occurring in young women ( $<35$ years) are different. Br J Cancer. 1996;74:1796-800.

5. Chung M, Chang HR, Bland KI, Wanebo HJ. Younger women with breast carcinoma have poorer prognoses than older women. Cancer. 1996;77:97-103.

6. Gajdos C, Tarrter PI, Bleiweiss IJ, Bodian C, Brower ST. Stage 0 to stage III breast cancer in young women. J Am Coll Surg. 2000;190:523-9.

7. Fowble BL, Schultz DJ, Overmoyer B, Solin LJ, Fox K, Jardines $\mathrm{L}$, Orel S, Glick JH. The influence of young age on outcome in early stage breast cancer. Int J Radiat Oncol Biol Phys. 1994 Aug 30;30:23-33.

8. Nixon AJ, Neuberg D, Hayes DF, Gelman R, Connolly JL, Schnitt S, Abner A, Recht A, Vicini F, Harris JR. Relationship of patient age to pathologic features of the tumor and prognosis for patients with stage I or II breast cancer. J Clin Oncol. 1994 May;12:888-94.

9. Han W, Kim SW, Park IA, Kang D, Kim SW, Youn YK, Oh SK, Choe KJ, Noh DY. Young age: an independent risk factor for disease-free survival in women with operable breast cancer. BMC Cancer. 2004 Nov 17;4:82.

10. Kataoka A, Iwamoto T, Tokunaga E, Tomotaki A, Kumamaru H, Miyata H, Niikura N, Kawai M, Anan K, Hayashi N, Masuda S, Tsugawa K, Aogi K, Ishida T, Masuoka H, Iijima K, Kinoshita T, Nakamura S, Tokuda Y. Young adult breast cancer patients have a poor prognosis independent of prognostic clinicopathological factors: a study from the Japanese Breast Cancer Registry. Breast Cancer Res Treat. 2016 Nov;160:163-72. doi: 10.1007/s10549-016-3984-8. Epub 2016 Sep 19.

11. van der Hage JA, Mieog JS, van de Velde CJ, Putter H, Bartelink $\mathrm{H}$, van de Vijver MJ. Impact of established prognostic factors and molecular subtype in very young breast cancer patients: pooled analysis of four EORTC randomized controlled trials. Breast Cancer Res. 2011 Jun 24;13(3):R68. doi: 10.1186/ bcr2908.

12. Filleron T, Dalenc F, Kramar A, Spielmann M, Levy Ch, Fumoleau P, Canon J-L, Martin A-L, Roché H. Prognostic factors of young women ( $\leq 35$ years) with node positive breast cancer: possible influence on post-therapeutic follow-up. Bull Cancer. 2013 Jul-Aug;100(7-8):22-9. doi: 10.1684/bdc. 2013.1791 
13. Singletary SE, Allred C, Ashley P. Revision of the American Joint Committee on Cancer staging system for breast cancer. J Clin Oncol. 2002;20(17):3628-36.

14. Edge SB, Compton CC. The American Joint Committee on Cancer: the $7^{\text {th }}$ edition of the AJCC cancer staging manual and the future of TNM. Ann Surg Oncol. 2010;17(6):1471-4. doi: 10.1245/s10434-010-0985-4.

15. Chen HL, Zhou MQ, Tian W, Meng KX, He HF. Effect of age on breast cancer patient prognoses: a population-based study using the SEER 18 database. PLoS One. 2016 Oct 31;11(10):e0165409. doi: 10.1371

16. Rosenberg LU, Magnusson C, Lindström E, Wedrén S, Hall P, Dickman PW. Menopausal hormone therapy and other breast cancer risk factors in relation to the risk of different histological subtypes of breast cancer: a case-control study. Breast Cancer Res. 2006;8(1):R11-10.1186/bcr1378.

17. Bertheau P, Steinberg SM, Cowan K, Merino MJ. Breast cancer in young women: clinicopathologic correlation. Semin Diagn Pathol. 1999 Aug;16(3):248-56.

18. Colleoni M, Rotmensz N, Robertson C, Orlando L, Viale G, Renne G, Luini A, Veronesi P, Intra M, Orecchia R, Catalano G, Galimberti V, Nolé F, Martinelli G, Goldhirsch A. Very young women ( $<35$ years) with operable breast cancer: features of disease at presentation. Ann Oncol. 2002;13:273-9.

19. Carter CL, Allen C, Henson DE. Relation of tumor size, lymph node status and survival in 24,740 breast cancer cases. Cancer. 1989;63:181-7.

20. Michaelson JS, Silverstein M, Wyatt J, et al. The prediction of breast cancer survival from tumor size. Cancer. 2002;95:713-23.

21. Rezo A, Dahlstrom J, Shadbolt B, Rodins K, Zhang Y, Davis AJ, et al. Tumor size and survival in multicentric and multifocal breast cancer. Breast. 2011 Jun;20(3):259-63. doi: 10.1016/j. breast.2011.01.005.

22. Neri A, Marrelli D, Megha T, Bettarini F, Tacchini D, De Franco L. Clinical significance of multifocal and multicentric breast cancers and choice of surgical treatment: a retrospective study on a series of 1158 cases. BMC Surg. 2015 Jan 14;15:1. doi: 10.1186/1471-2482-15-1.

23. Fisher B, Bauer M, Wickerham DL, et al. Relation of the number of positive axillary nodes to the prognosis of patients with primary breast cancer. An NSABP update. Cancer. 1983;52: 1551-7.

24. Tai P, Yu E, Joseph K. Prognostic significance of number of positive nodes: a long-term study of one to two nodes versus three nodes in breast cancer patients. Int J Radiat Oncol Biol Phys. 2010;77:180-7. doi: 10.1016/j.ijrobp.2009.04.073.

25. Dent R, Trudeau M, Pritchard KI, Hanna WM, Kahn HK, Sawka CA, et al. Triple-negative breast cancer: clinical features and patterns of recurrence. Clin Cancer Res. 2007;13(15 Pt 1): 4429-34.

26. Abubakar M, Orr N, Daley F, Coulson P, Ali HR, Blows F, et al. Prognostic value of automated KI67 scoring in breast cancer: a centralised evaluation of 8088 patients from 10 study groups. Breast Cancer Res. 2016;18(1):104. doi: 10.1186/ s13058-016-0765-6.

27. Munzone E, Botteri E, Sciandivasci A, Curigliano G, Nole F, Mastropasqua M, Rotmensz N, Colleoni M, Esposito A, Adamoli L. Prognostic value of Ki-67 labeling index in patients with node-negative, triple-negative breast cancer. Breast Cancer Res Treat. 2012;134:277-82. doi: 10.1007/s10549-0122040-6.

28. Veronesi U, Cascinelli N, Mariani L, Greco M, Saccozzi R, Luini A, et al. Twenty-year follow-up of a randomized study comparing breast-conserving surgery with radical mastectomy for early breast cancer. N Engl J Med. 2002;347(16):1227-32.

29. Fisher B, Jeong JH, Anderson S, Bryant J, Fisher ER, Wolmark N. Twenty-five-year follow-up of a randomized trial comparing radical mastectomy, total mastectomy, and total mastectomy followed by irradiation. N Engl J Med. 2002;347: 567-75. 


\section{Sažetak \\ NEOVISNI ČIMBENICI ZA LOŠU PROGNOZU KOD MLADIH BOLESNICA S RAKOM DOJKE I.-III. STADIJA}

\section{Eriç, A. Petek Eric, I. Koprivucič, M. Babic, S. Pačarić i B. Trogrlić}

Rak dojke je najčešći zloćudni tumor u populaciji žena u dobi ispod 40 godina. Mlada dob je neovisan čimbenik za lošu prognozu. Željeli smo utvrditi i druge čimbenike loše prognoze kod raka dojke I.-III. stadija kod mlade populacije žena. Uzeli smo u obzir sljedeće parametre: veličinu tumora, stanje limfnih čvorova, histološki stupanj, status hormonskih receptora, Ki-67 prognostički indeks, HER2 neu status, histološki tip tumora, lokalni recidiv i razvoj udaljenih metastaza. Logistička regresija korištena je za procjenu utjecaja čimbenika na vjerojatnost smrtnog ishoda i razvoja udaljenih metastaza. Naše bolesnice imale su većinom tumor T1 (49,4\%), pozitivne limfne čvorove (62\%), a većina njih bile su pN1 (61,2\%). Do jedne trećine bolesnica imale su trostruko negativan hormonski status. Ki-67 indeks proliferacije bio je visokih 25\%. Našli smo učestalost multicentričnog tumora kod $23 \%$ bolesnice. Nije bilo razlike u preživljenju između dviju vrsta kirurškog zahvata. Bolesnice sa statusom limfnih čvorova pN0 imale su bolje preživljenje. Rak dojke kod mlade populacije žena ima agresivniju prirodu. Rezultati istraživanja ukazali su na pozitivan status limfnih čvorova kao nezavisan čimbenik za lošu prognozu raka dojke I.-III. stadija.

Ključne riječi: Karcinom dojke; Mlade žene; Multivarijatna analiza; Nezavisni čimbenik rizika 